\title{
Growth patterns of Pinus sylvestris across Europe: a functional analysis using the HYDRALL model
}

\begin{abstract}
Magnani $F^{(1)}$, Nolè $A^{(2)}$, Ripullone $F^{(2)}$, Grace $\mathrm{J}^{(3)}$
The variability of Pinus sylvestris growth over two geographic transects across Europe has been explored through a process-based forest growth model (HYDRALL: HYDRaulic constraints on ALLocation) which accounts for the effects of environmental conditions not only on short-term gas exchanges, but also on allocation and tree structure. The model has been validated against both eddycovariance and growth data under contrasting environmental conditions. Forest growth was found to be reduced by low temperatures $(-50 \%)$ and water stress $(-37 \%)$ at the opposite extremes of the natural range of the species. Application of a functional model made it possible to partition growth reductions between individual processes. Gross primary production was severely affected by low temperatures and short vegetative periods at the northern extreme of the specific range $(-53 \%)$, and by low air and soil humidity at the southern limit $(-26 \%)$. The ratio between net and gross primary production was found to be rather constant across the temperate region, only increasing in the boreal zone in response to low temperatures $(+20 \%)$. Under dry conditions, on the contrary, a substantial proportion of the reduction in aboveground productivity was attributed to the need to allocate increasing amounts of resources to fine root production and maintenance $(+16 \%)$. Both short and long-term responses should be considered in the prediction of climate change impact on forests.
\end{abstract}

Keywords: Allocation, ANPP, Geographic variation, GPP, Precipitation, Scots pine, Temperature

\section{Introduction}

Forest growth is affected in a complex way by a variety of climatic factors, resulting for every species in large differences in productivity across its natural range. Moreover, the analysis of regional patterns of growth could prove a useful tool for the prediction of the future effects of climate change on forest productivity (Breymeyer et al. 1996). In fact severe regional heat waves coupled with drought events, like that of summer 2003, have become more frequent in the last decade especially in central and eastern Europe (Schar et al. 2004). These disturbances affect forest productivity with tree

(1) Department of Plant Cultivation, University of Bologna, Italy; (2) Department of Crop System, Forestry and Environmental Sciences, University of Basilicata, Italy; (3) IERM, University of Edinburgh, United Kingdom

\section{@ Angelo Nolé (nole@unibas.it)}

Received: Aug 07, 2008 - Accepted: Oct 06, 2009

Citation: Magnani F, Nolè A, Ripullone F, Grace J, 2009. Growth patterns of Pinus sylvestris across Europe: a functional analysis using the HYDRALL model. iForest 2: 162-171 [online: 2009-10-15] URL: http://www.sisef.it/iforest/show.php? id $=516$ damages, changes in litterfall and fine root growth rates, and more in general with changes in forests carbon pools with consequences beyond the duration of the extreme climate event (Ciais et al. 2005). Under this climate change scenario a clear definition not only of what are the physical limiting factors on forest growth, but also of the mechanisms that are involved is central to our understanding of forest function.

Scots pine (Pinus sylvestris L.) is the most widely distributed conifer in the world (Boratynski 1991), its range extending to large areas of Europe and Asia, covering a wide variety of environmental conditions within this natural range; this distribution reflects the large variability in productivity displayed by the species.

The species extends as far north as $70{ }^{\circ} \mathrm{N}$ on the Norwegian coast, reaching $37^{\circ} \mathrm{N}$ at its southern limit in the Sierra Nevada of Spain; the longitudinal range covers most of Europe, spreading over Siberia as far as 138 ${ }^{\circ} \mathrm{E}$. Although unevenly distributed, Scots pine stands contribute to a large proportion of European forests, comprising for example almost $65 \%$ of the total forest cover of Finland (Sevola 1998), about 20\% of all high forests in the United Kingdom (Christie \& Lines 1979) and $9 \%$ of the forested area of France (Bazire \& Gadant 1991). Christie \& Lines (1979), in a comparison of growth and yield data from Scots pine forest around Europe, reviewed national maximum mean annual increments ranging from just above 2 to more than $18 \mathrm{~m}^{3} \mathrm{ha}^{-1} \mathrm{yr}^{-1}$. Since all these figures refer to optimal fertility conditions at national level, observed differences could be attributed to purely climatic factors. An interpretation of differences in growth, physiological responses and structural traits in terms of regional climate has been attempted by several studies, to identify the key limiting factors for Scots pine intraspecific climate-driven adjustments (Ineson et al. 1984, Mencuccini \& Bonosi 2001, Poyatos et al. 2007).

Key processes like transpiration, photosynthesis and respiration have been largely dissected, enabling to successfully predict the response of leaves to most environmental factors (Farquhar \& von Caemmerer 1982, Leuning 1995). Moreover, simple schemes have been devised to up-scale leaf gas-exchanges to the stand and ecosystem level (Choudhury \& Monteith 1988, De Pury \& Farquhar 1997), leading to the development of reliable models of canopy function.

The response to the environment of other processes such as carbon allocation is still poorly understood, although several approaches have been proposed (Cannell \& Dewar 1994, Friedlingstein et al. 1999, Högberg et al. 2002, Bird \& Torn 2006, Litton et al. 2007). One of the hypothesis is that observed changes in growth allocation, both over the lifetime of the plant and in response to the environment, could be explained in coniferous species by a common framework, based on the observation of a functional homeostasis in water transport and on the assumption of optimal plant adaptation to a variable environment (Magnani et al. 2000, Magnani et al. 2002). In a common garden trial of 19 European Scots pine provenances Oleksyn et al. (2003) demonstrates a significant relationship between ANPP and the latitude and longitude of the site of origin, this is in agreement with the hypothesis that optimality in tree structure results from longterm adaptation to local climate, rather than short-term acclimation to instantaneous site conditions.

This hypothesis has been implemented in a detailed forest growth model, which represents the adjustment of both foliage function and tree structure to the environment. In the present work, the newly developed model will be used to try and explain in detail the geographic variability of Scots pine growth across Europe. The results will highlight the sensitivity of the species to key environmental parameters, laying the ground for the prediction of its response to future climate change. 


\section{Material and methods}

The HydRall (HYDRaulic constraints on ALLocation) model the growth of a coniferous forest stand over a whole rotation. The model focuses on the key determinants of plant growth: light interception and gas exchanges, water relations and growth allocation. The main model outputs are produced by the model on a yearly time step: stand density and height, gross and net primary production (GPP and NPP), net ecosystem exchange (NEE), transpiration (E), total tree biomass and its distribution among plant organs: leaves, stem (including branches and coarse roots) and fine roots. A complete description of the HydRaLl model can be found in Magnani et al. (2004). In comparison with other existing forest growth models, growth allocation among tree organs is not fixed, but responds dynamically to internal and external conditions. The representation of other processes is based on well established models; a brief description of the key model features follows.

\section{Light absorption by the canopy}

The representation of global radiation absorption by the sunlit and the shaded portion of a coniferous canopy is based on the twoleaf model of De Pury \& Farquhar (1997). The same approach is also used for the computation of foliage isothermal net radiation, a key variable in canopy transpiration. Light scattering and absorption in the visible, nearinfrared and long-wave bands are modelled following Goudriaan \& van Laar (1994). An extinction coefficient of direct radiation for non-horizontal black leaves has been computed following Ross (1981), assuming a spherical leaf angle distribution. Reflection coefficients for visible and near-infrared radiation are also computed following Goudriaan \& van Laar (1994), under the simplifying assumption of a common coefficient for the ground and the canopy, as could be expected if the soil is covered by a dense understorey.

\section{Vertical functional gradients}

Leaf photosynthetic parameters are integrated over sunlit and shaded foliage and adjusted as a function of absorbed photosynthetically active radiation (PPFD) and leaf temperature. The up-scaling of photosynthetic properties over the canopy is based on the approach of De Pury \& Farquhar (1997). A vertical exponential profile of leaf nitrogen content over the canopy is assumed, parallel to the reduction in diffuse $P P F D$, and both dark respiration and maximum carboxylation rates are assumed to be proportional to leaf nitrogen (Ryan 1995, Leuning 1997).

\section{Aerodynamic decoupling}

Aerodynamic decoupling could have substantial effects on the gas-exchange of short, dense coniferous forests (Shaw \& Pereira 1982). Stand aerodynamic conductance is therefore computed iteratively in the model, following Monteith \& Unsworth (1990) and Garratt (1992), as a function of wind speed and sensible heat flux from the canopy. Appropriate values of zero plane displacement and roughness length as a function of stand leaf area index and height have been derived from Shaw \& Pereira (1982). Near-field resistance to heat exchange is integrated over the whole canopy following the approach of Choudhury \& Monteith (1988).

\section{Stand gas-exchange and respiration}

The conductance and gas-exchanges of sunlit and shaded foliage are computed separately on a half-hourly basis. The representation of leaf assimilation is based on the Farquhar model (Farquhar \& von Caemmerer 1982). The response of leaf assimilation to PPFD follows Farquhar \& Wong (1984). The dependence of stomatal conductance upon assimilation and air vapour pressure deficit is captured by the Leuning (1995) model, whilst a simple linear dependence of stomatal conductance upon soil water potential is assumed. Finally, following Landsberg \& Waring (1997), it is assumed that no gasexchange takes place whenever minimum daily temperature falls below zero. Sapwood and fine root respiration are a function of average daily temperature, tissue biomass and nitrogen content, as suggested by Ryan (1991). The empirical model presented by Lloyd \& Taylor (1994) is used to represent the dependence of tissue (and soil) respiration upon temperature, instead of the more common $Q_{10}$ approach, to account for the often observed shift in $Q_{10}$ with temperature (Tjoelker et al. 2001). Growth respiration, finally, is assumed to be a constant fraction of available carbon (Thornley \& Johnson 1990).

\section{Understorey gas-exchange and site wa-} ter balance

The representation of transpiration and net carbon exchange from a generic understorey is based on the approach proposed by Dewar (1997), who adapted and evaluated the RESCAP model (RESource CAPture - Monteith 1986, Monteith et al. 1989) for the evaluation of forest growth and forest transpiration.

According to this approach, gas exchanges are limited either by maximum potential photosynthesis, proportional to absorbed light, or by maximum potential transpiration, which is a function of soil water content. Water-use efficiency (WUE, carbon gain per water lost) is modulated by both air humidity and atmospheric $\mathrm{CO}_{2}$ concentration (Jones 1992). The seasonal pattern of understorey foliage and root growth is derived from computed assimilation, assuming a constant ratio between net and gross primary production (Waring et al. 1998) and a constant coefficient of allocation to fine roots.

Canopy interception is assumed to be a fixed proportion of incoming precipitation, and superficial run-off takes place whenever the water content of the single-layer of soil exceeds soil porosity. Water drainage to a water table at a constant depth of $20 \mathrm{~m}$ is represented following Campbell (1985). A rooting depth of $1 \mathrm{~m}$ and a soil sand fraction of 0.85 were assumed in all simulations.

\section{Foliage water relations}

Because of its effects on allocation and growth, the transport of water through the soil-plant continuum has been modelled in detail as described in Magnani et al. (2002). Soil water potential and hydraulic resistance are a function of soil water content and texture and of fine root density (Campbell 1985). Root resistance is assumed to be inversely related to fine root biomass (Magnani et al. 1996), whilst aboveground resistance is a simple function of sapwood basal area and tree height (Whitehead et al. 1984). Such a crude formulation has been shown to be appropriate in the case of $P$. sylvestris (Magnani et al. 2000). Values of soil, root and sapwood hydraulic resistance are then adjusted for the effects of temperature (Magnani et al. 2002)

\section{Growth and mortality}

An annual time step has been chosen in the representation of mortality and stand growth, a reasonable simplification in evergreen conifers. Growth allocation among foliage, sapwood and fine roots is driven by the assumption of optimal plant growth under hydraulic constraints (Magnani et al. 2000, Magnani et al. 2002). Evolution is assumed to have resulted in an allocation strategy that maximizes plant fitness within the limits imposed by the species' functional characteristics and by the environment. Height has been chosen as a fitness criterion to be maximized, because of its role in inter-individual competition and plant survival in closed canopies. Height increments are assumed to be proportional to the difference between foliage production and foliage turnover, as if new foliage, after replenishing the existing crown, formed a new layer over the top of the canopy with a fixed foliage density; the relationship was parameterized using data from Ovington (1957).

The constraints imposed by the environment on foliage production and height increments are depicted in Fig. 1. Were all resources to be allocated to foliage growth, this would result in extremely negative values of leaf water potential over the course of the year, threatening the survival of the plant (Tyree \& Sperry 1989). Minimum leaf water potential, on the contrary, has been found to 


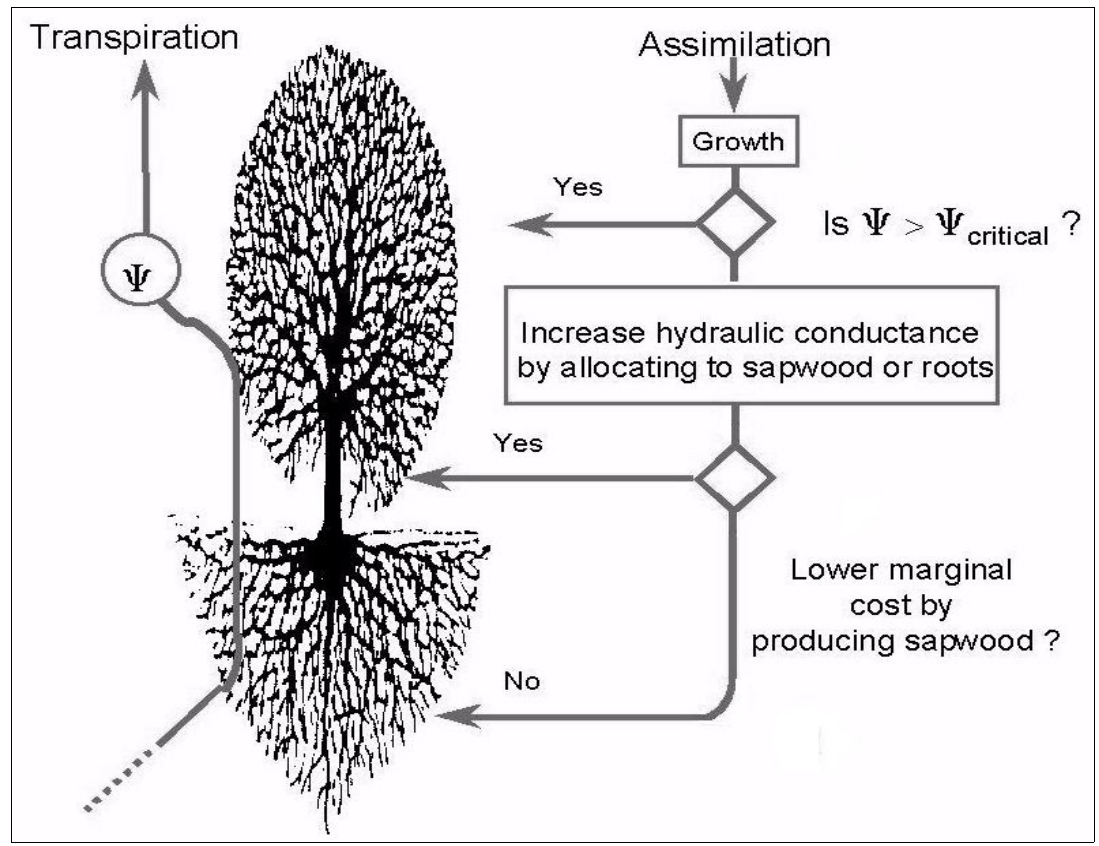

Fig. 1 - Flow diagram illustrating the criteria for growth allocation according to the hypothesis of functional homeostasis in water transport (Magnani et al. 2000, Magnani et al. 2002). Allocation to foliage is maximized, as long as it does not induce leaf water potentials exceeding a safety range. Allocation between sapwood and fine roots, according to the principle of optimality, maximizes the return of new hydraulic conductance from carbon investment, so as to free more resources for foliage and height increments.

be rather constant over a range of environmental conditions and developmental stages, as reviewed for $P$. sylvestris by Magnani (2000). If this functional homeostasis is to be maintained, allocation has to favour transport tissues over foliage growth in ageing stands or under stress conditions, as often observed (Axelsson \& Axelsson 1986, Mencuccini \& Grace 1995, Mencuccini \& Grace 1996a). Optimal height growth, moreover, requires that resources be allocated among transport tissues in an efficient way, in order to increase hydraulic conductance at the lowest possible carbon cost. This results in an age-independent ratio between sapwood area and fine root biomass (Magnani et al. 2000). The balance, however, is strongly affected by environmental conditions, more carbon being allocated to feeder roots under stress conditions, in good agreement with experimental evidence (Santantonio 1989, Gholz et al. 1994).

Finally, stand density is progressively reduced either by imposed thinnings or by distance-dependent mortality, represented by the self-thinning law (Westoby 1984). Both thinnings and mortality are assumed to reduce not only stand volume, but also foliage biomass and other living tissues to the same extent. A fixed proportion of tissue biomass is also lost every year through turnover (Thornley \& Johnson 1990).

\section{Soil carbon dynamics}

The two-compartment model of Andrén \& Kätterer 1997 has been chosen to represent soil respiration and the transition from young to old soil carbon pools. A constant humidification coefficient is assumed. Decomposition of young and old organic matter and humidification are affected to the same extent by soil temperature and soil water potential, as captured by the multiplicative model of Andrén \& Paustian (1987).

\section{Weather simulation}

The model relies for its input on monthly climatological data, as provided for the whole of Europe by the LINK data-set (Hulme et al. 1995).

Air temperature is derived from daily maximum and minimum temperature as described by Goudriaan \& van Laar (1994). An average daily value of atmospheric transmissivity is obtained from relative heliophany, according to the Angstrom model (Maracchi et al. 1983). Based on this value, instantaneous global radiation and the fraction of diffuse radiation are then computed (Goudriaan \& van Laar 1994). Downward long-wave irradiance is derived from air temperature and atmospheric emissivity, which in turn is assumed to be under clear conditions a function of air vapour pressure and temperature, as predicted by the Brutsaert's model (Kustas et al. 1989). The effects of cloudiness on atmospheric emissivity are represented following Monteith \& Unsworth (1990).

Air vapour pressure is assumed to be constant over the day (Goudriaan \& van Laar 1994). Dew-point temperature is computed as described by Kimball et al. (1997). Instantaneous vapour pressure deficit is then obtained as the difference from saturated air humidity, derived from Teten's equation (Jones 1992).

\section{Model simulations}

A summary of functional parameters for $P$. sylvestris applied in the model is reported in Box 1. These correspond to conditions of good nutrient availability, so as to be able to analyse the effects of climate alone. The model, in its present form, does not take into account site-specific differences in any functional parameters other than below-ground allocation. This assumption is supported by a previous study by Oleksyn et al. (2003) in which the observed differences in leaf $\mathrm{N}$ concentration, a parameter of particular interest because of its relationship with photosynthetic potentials, amounted to no more than $15 \%$ over a latitudinal range of more than $20^{\circ}$, and opposite trends were observed in situ and in a common garden experiment. Moreover Poyatos et al. (2007) demonstrate

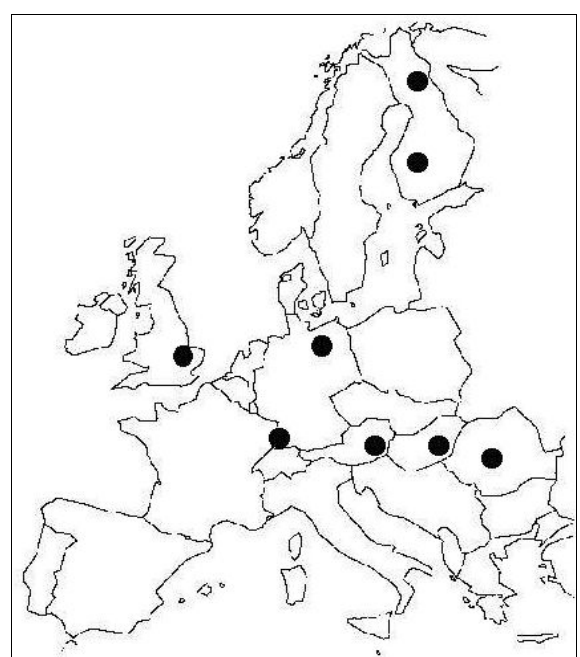

Fig. 2 - Location of sites considered in the simulation. The range of sites encompasses a latitudinal transect from Northern Finland to Southern Germany, as well as a longitudinal transect from South-east England to $\mathrm{Ru}$ mania. 
Tab. 1 - Location of sites considered in the simulation and key climatic characteristics: average annual temperature, July temperature, annual precipitation $(P)$ and the ratio between potential evapotranspiration (PET) and precipitation. Potential evapotranspiration is based on the Priestley and Taylor model (Priestley \& Taylor 1972), assuming an average net longwave irradiance of $60 \mathrm{~W} \mathrm{~m}^{-2}$.

\begin{tabular}{|c|c|c|c|c|c|c|}
\hline Site & Latitude & Longitude & $\begin{array}{c}\text { Annual } T \\
\left({ }^{\circ} \mathbf{C}\right)\end{array}$ & $\begin{array}{c}\text { July } T \\
\left({ }^{\circ} \mathbf{C}\right)\end{array}$ & $\begin{array}{c}\mathbf{P} \\
\left(\mathbf{m m} \mathbf{y r}^{-1}\right)\end{array}$ & $P E T / P$ \\
\hline N Finland & $67^{\circ} 15^{\prime}$ & $29^{\circ} 15^{\prime}$ & -1.9 & 10.0 & 524 & 0.45 \\
\hline S Finland & $62^{\circ} 15^{\prime}$ & $24^{\circ} 15^{\prime}$ & 3.2 & 14.1 & 503 & 0.69 \\
\hline N Germany & $53^{\circ} 15^{\prime}$ & $13^{\circ} 15^{\prime}$ & 8.6 & 16.0 & 535 & 1.16 \\
\hline E England & $52^{\circ} 15^{\prime}$ & $0^{\circ} 45^{\prime}$ & 9.1 & 14.0 & 564 & 0.94 \\
\hline S Germany & $47^{\circ} 15^{\prime}$ & $7^{\circ} 15^{\prime}$ & 10.4 & 17.6 & 963 & 0.74 \\
\hline Austria & $47^{\circ} 15^{\prime}$ & $15^{\circ} 15^{\prime}$ & 9.0 & 17.4 & 715 & 1.04 \\
\hline Hungary & $47^{\circ} 15^{\prime}$ & $21^{\circ} 15^{\prime}$ & 10.3 & 18.7 & 481 & 1.83 \\
\hline Rumania & $46^{\circ} 15^{\prime}$ & $24^{\circ} 15^{\prime}$ & 9.5 & 18.0 & 476 & 1.72 \\
\hline
\end{tabular}

Fig. 3 - Test of model predictions. The development of mean height and stand volume predicted by the model for Southeast England (thick line) and Central Finland (thin line) are compared with figures from British Growth \& Yield tables (black circles, Edwards \& Christie 1981, YC 14, intermediate thinning) and from Finnish permanent sample plots (white circles, R. Sievanen, unpublished data). Prescribed thinnings were applied in the simulation for SE England, whilst self-thinning only was assumed for the Finnish stand.

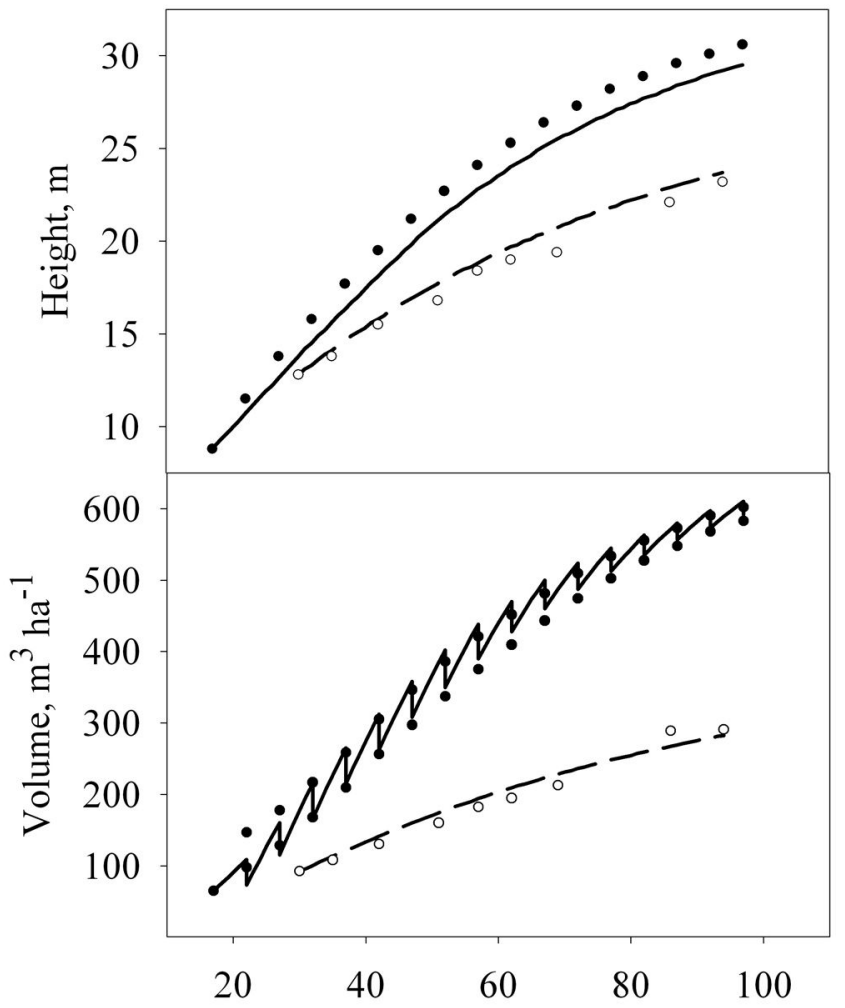

Age, yrs

Tab. 2 - Sensitivity of selected growth variables to key environmental factors. Percentage changes in stand height $(\mathrm{H})$ and total volume at 100 years $\left(\mathrm{V}_{\text {tot }}\right)$, average gross $(\mathrm{GPP})$ and net primary production (NPP) and fraction allocated to fine root production $\left(\lambda_{\mathrm{r}}\right)$ as a result of imposed changes in air temperature and precipitation. Sensitivity is defined as $\mathrm{S}=\left(\mathrm{O}_{1}-\mathrm{O}_{0}\right) / \mathrm{O}_{0}$ where $\mathrm{O}_{0}$ and $\mathrm{O}_{1}$ are model output under reference and changed conditions.

\begin{tabular}{lcccrrr}
\hline Parameter & Change & $\begin{array}{c}\mathbf{H} \\
\mathbf{( \% )}\end{array}$ & $\begin{array}{c}\boldsymbol{V}_{\text {tot }} \\
(\mathbf{\%})\end{array}$ & $\begin{array}{c}\text { GPP } \\
\mathbf{( \% )}\end{array}$ & $\begin{array}{c}\text { NPP } \\
(\mathbf{\%})\end{array}$ & \multicolumn{1}{c}{$\begin{array}{c}\boldsymbol{\lambda}_{\mathbf{r}} \\
\mathbf{( \% )}\end{array}$} \\
\hline \multirow{2}{*}{ Temperature } & $+2{ }^{\circ} \mathrm{C}$ & -5.2 & -6.7 & 3.2 & -1.5 & 7.6 \\
& $-2{ }^{\circ} \mathrm{C}$ & -8.6 & -21.4 & -22.7 & -19.0 & -0.4 \\
Precipitation & $+10 \%$ & 1.0 & 1.5 & -0.4 & -0.6 & -3.1 \\
& $-10 \%$ & -2.4 & -2.4 & 0.6 & 1.1 & 4.6 \\
\cline { 2 - 7 }
\end{tabular}

that, similar to hydraulic architecture, also stomatal conductance and its response to air and soil humidity change in Scots pine populations across Europe, but they attribute observed differences to acclimation rather than ecotype adaptation to site conditions.

Once tested against both growth and functional data, the model has been applied to simulate Scots pine growth along two regional transects across Europe (Fig. 2 and Tab. 1). The transects explore a latitudinal gradient from Northern Finland to Southern Germany and a longitudinal one from the maritime climate of England to the more dry and continental climate of Rumania, at the south-eastern limit of the species range.

In contrast with site-specific model validation, no differences in soil texture and depth were considered in regional simulations, since soil characteristics vary on a much finer scale than climate and no clear patterns are apparent at the continental level.

A list of the sites and of their key climatic characteristics is reported in Tab. 1. At all sites, climatic characteristics correspond to the lowest elevation in the LINK data-base (Hulme et al. 1995). A very high initial stocking density of $5 \times 10^{4}$ trees $\mathrm{ha}^{-1}$, as would be expected in a naturally regenerating stand (Ovington 1957), and no artificial thinning was assumed throughout, so as to neglect any national differences in management regimes.

Temperature and water availability are among the main limiting factors for plant growth on a regional scale. The sensitivity of model predictions to a temperature change of $\pm 2{ }^{\circ} \mathrm{C}$ and to $\mathrm{a} \pm 10 \%$ shift in precipitation has been therefore analysed in detail, taking the climate of south-east England as a reference, so as to be able to interpret the pattern observed along the European transects.

\section{Model results}

Model results for two locations in southeast England and Central Finland, respectively, are reported in Fig. 3 and compared with predictions from local Growth \& Yield tables (Edwards \& Christie 1981) and permanent sample plots (Sievanen, unpublished data). The systematic error in height predictions at the British site is partly explained by the fact that average stand height, as predicted by the model, is compared with tabulated values of top height.

Additional support for the model comes from a comparison (Fig. 4) with literature data of annual aboveground net primary production $(A N P P)$ from a Scots pine chronosequence in Thetford Forest (Sussex, UK Ovington 1957, Mencuccini \& Grace 1996b) and from a number of sites around Jädraås (Sweden - Albrektson \& Valinger 1985). Both the age-related decline in productivity and the marked differences in ANPP between the two locations are well captured 
by the model.

An analysis of model sensitivity demonstrates (Tab. 2) that both height and total volume are negatively affected by a temperature change in either direction, but for different reasons: warming, on the one hand, would beneficially affect canopy photosynthesis, but because of the direct effect on respiration a slight reduction in net primary production would be expected. Moreover, allocation to fine roots is predicted to increase under warmer conditions as a result of higher transpiration rates, leading to an overall reduction in aboveground increments. Colder conditions, on the other hand, would mainly result in lower gross primary production, whilst only marginal changes in respiration and carbon allocation are predicted. Starting from the relatively mild British conditions, precipitation changes are predicted to have a relatively minor effect on growth, mainly the result of a shift in the allocation pattern.

When values of stand height and total (standing plus self-thinned) volume after 100 years are compared across Europe, a rather clear picture emerges (Fig. 5), with a marked decline in final height and even more in total volume moving northwards and eastwards. The lowest volume increments are predicted at the northern limit of the range $(50 \%$ of the maximum, corresponding to south-east England), while modelled values for $\mathrm{Ru}-$ manian stands at the south-eastern extreme are still $63 \%$ of the maximum. Differences between sites are not limited to final values but involve the dynamics of height and volume growth (Fig. 6).

The relationship between height and total volume increments is known to be rather constant at any particular site (Eichorn 1904), but quite variable at the regional scale (Christie \& Lines 1979). This variability is captured by the model, as shown in Fig. 7: the slope of the relationship is highest at the most productive sites, since total volume production is more strongly reduced than height under limiting environmental conditions (Fig. 5).

Stand aboveground net primary production (and stand current annual increment, which is closely related to $A N P P$ ) is the result of three processes, acting in series: stand gross primary production $(G P P)$ is reduced by respiration to net primary production $(N P P)$ which is allocated above- and below-ground. In mathematical terms (eqn. 1):

$$
A N P P=\frac{G P P \cdot N P P}{G P P} \cdot\left(1-\lambda_{r}\right)
$$

where $\lambda_{\mathrm{r}}$ represents the fraction of $N P P$ allocated below-ground. When the relative contribution of the three terms is compared across Europe, the functional determinants of growth differences can be better understood. When figures are normalized to optimum values (Fig. 8), it can be seen that at

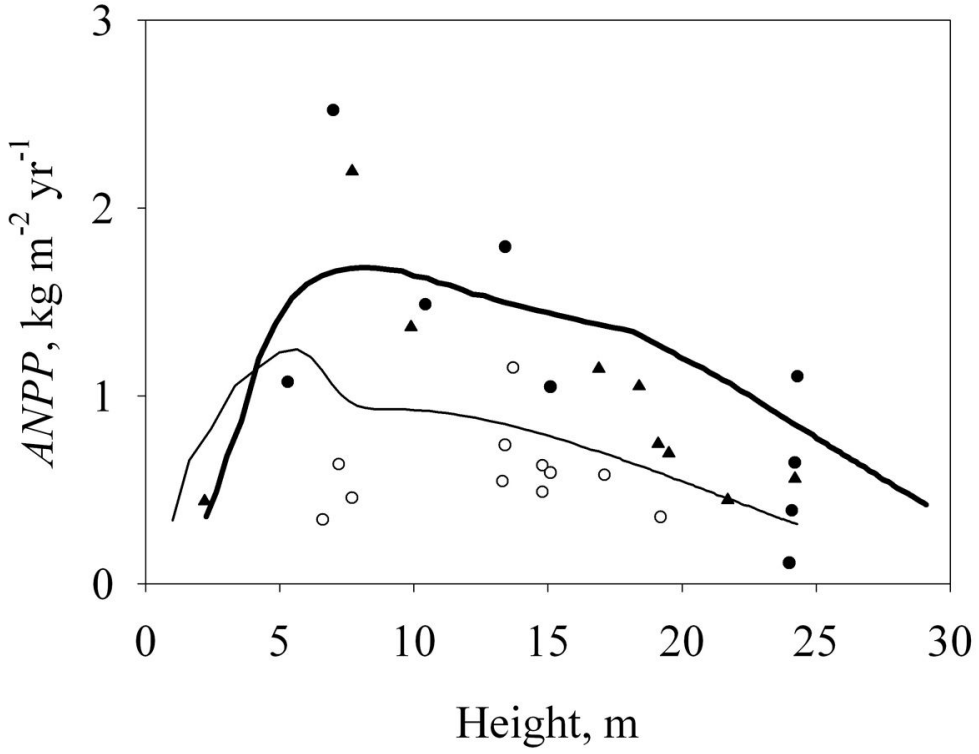

Fig. 4 - Test of model predictions. The development of stand above-ground net primary production (ANPP) predicted by the model for south-east England (thick line) and central Sweden (thin line) are compared with experimental data from a Scots pine chronosequence in Thetford Forest, UK (black circles, Ovington 1957; black triangles, Mencuccini \& Grace 1996) and from a series of sites around Jädraås, Sweden (white circles, Albrektson \& Valinger 1985).

the northern limit of the range the reduction in gross primary production $(-53 \%)$ exceeds the corresponding value for growth $(-50 \%$; Fig. 5), as low temperatures also reduce the proportion of available carbon that is lost

through respiration. The opposite is true at the dry limit of the range, where a $26 \%$ reduction in GPP translates in a $36 \%$ decline in growth rates. In this case the discrepancy is the result not of respiration differences,

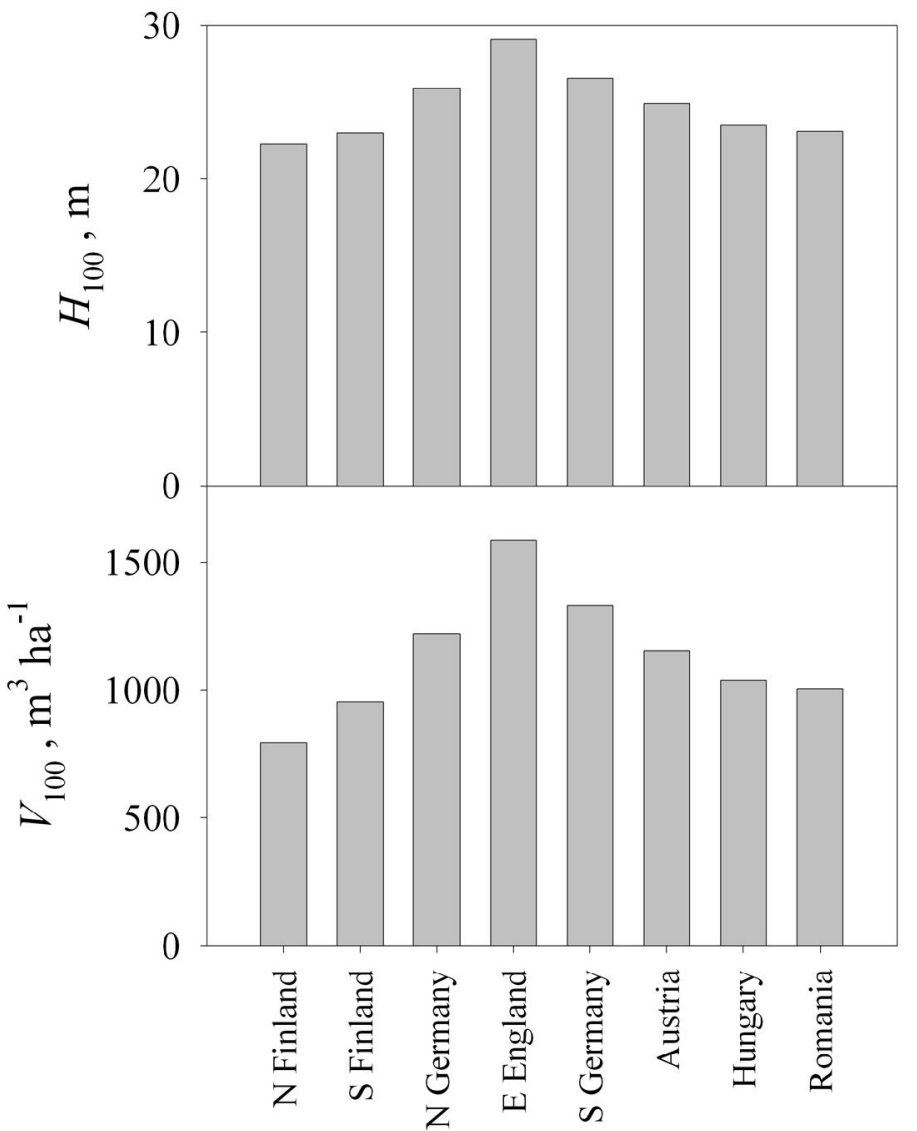

Fig. 5 - Simulated height $\left(\mathrm{H}_{100}\right)$ and total volume at age $100\left(\mathrm{~V}_{100}\right)$ for a range of sites along two latitudinal and longitudinal transects across Europe. 
Fig. 6 - Simulated development of stand height and total volume for a range of sites across Europe. Results are reported for Southeast England (continuous thick), Northern Finland (dash-dot), Northern Germany (dotted), Southern Germany (continuous thin) and Rumania (dashed line).

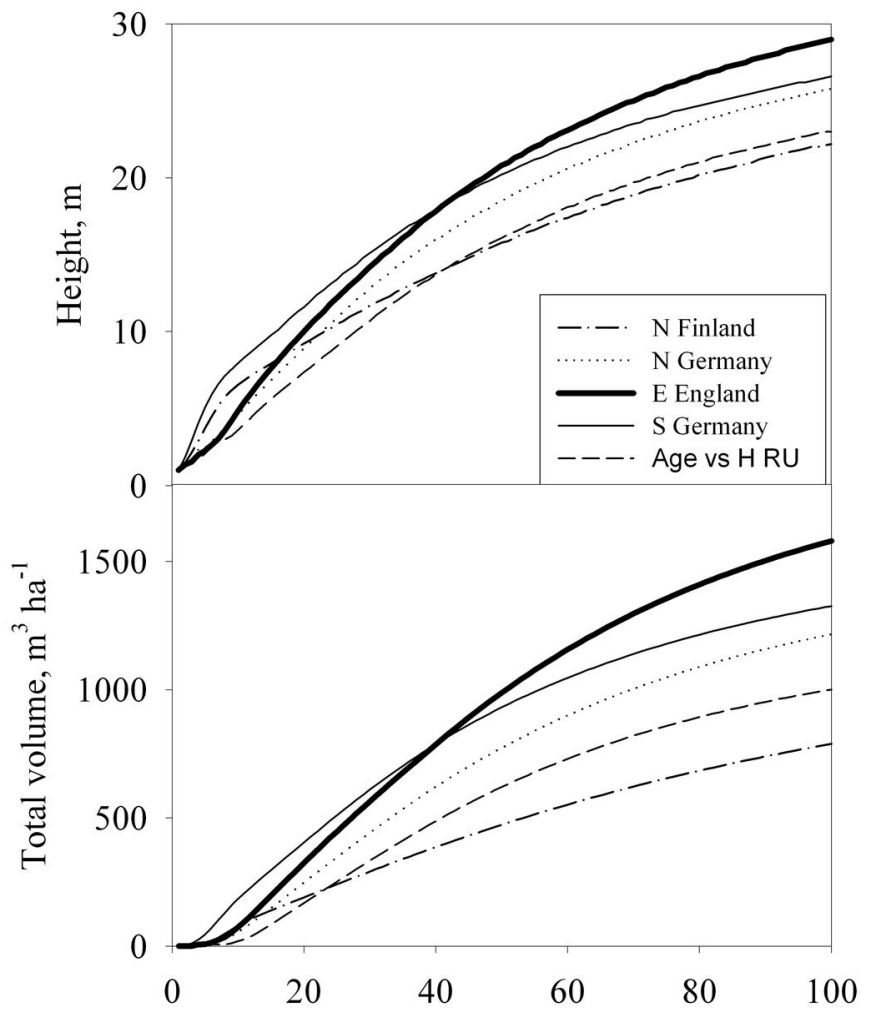

Age, yrs

but of greater below-ground allocation $(+13$ $\%)$.

\section{Discussion}

Several components of the model have already been independently tested, lending credibility to model results (Magnani et al. 2004). Annual dynamics of gas exchange have been successfully compared with eddy- covariance data from three pine forests across Europe (Kramer et al. 2002). The response of resource allocation and growth to age and the environment has also been tested against field and literature data (Magnani et al. 2000, 2002). An additional confirmation of the predictive ability of the model comes from the comparison with $P$. sylvestris growth dynamics at contrasting sites (Fig. 3

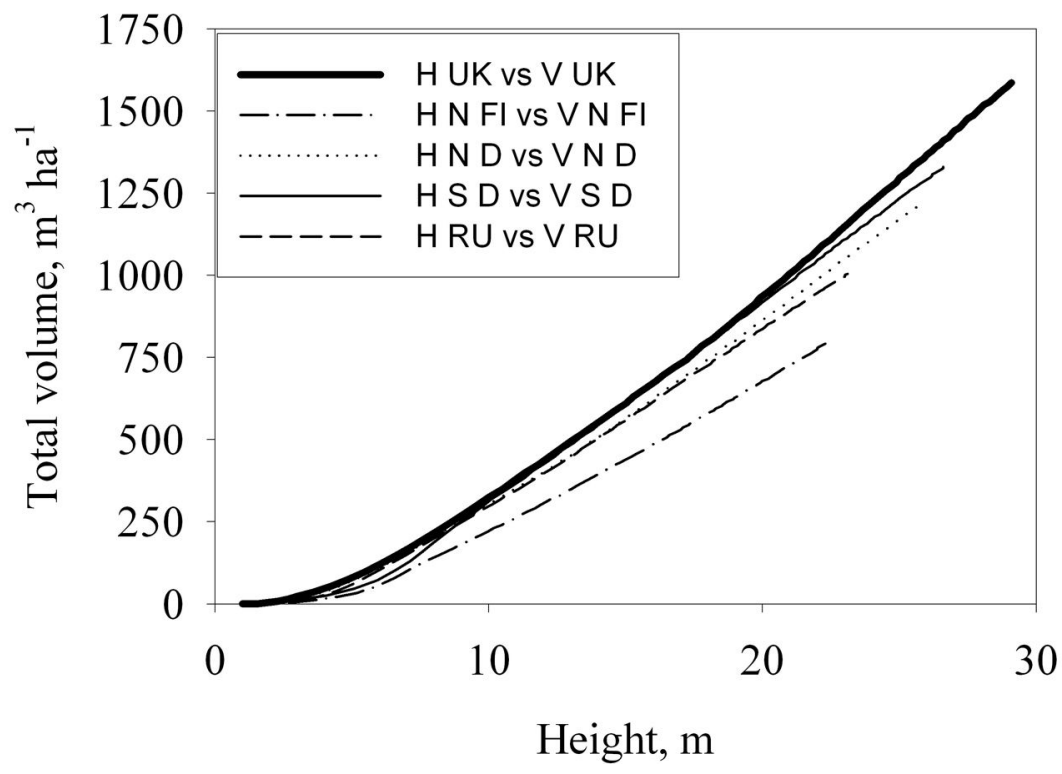

Fig. 7 - Simulated total volume production-height curves for a range of sites across Europe. See Fig. 6 for legends.

and Fig. 4). The sites differ considerably in latitude, climate and applied management regimes; the good agreement between modelled and measured data should be therefore viewed as a confirmation of the precision and generality of the model.

Scots pine seems to find near-optimal conditions in the English climate (Christie \& Lines 1979). It is therefore not surprising that, according to the sensitivity analysis reported in Tab. 2, growth would be reduced both by an increase and by a decrease in temperature, although by different mechanisms. Cold temperatures would mainly impair photosynthesis and net carbon exchange, in particular cold soil temperatures can affect the transpiration deficit during spring with negative effects on forest productivity (Mellander et al. 2004). On the other hand, a climate warming would result in higher vapour pressure deficits inducing higher transpiration rates. In these warmer climate conditions, a decrease in soil water availability could affect forest productivity with a shift in carbon allocation resulting in a decrease of green parts, and at the same time in a greater allocation to below-ground fractions (Lapenis et al. 2005). This apparent sensitivity to water stress is confirmed by the response to changes in precipitation (Tab. 2) and is consistent with the conclusions by White (1982) that variations in P. sylvestris productivity in Great Britain are associated primarily with changes in solar radiation and soil water balance. Moreover, in recent studies Briceno-Elizondo et al. (2006) have modelled the effect of solar radiation availability on southern and northern Finland Scots pine stands under climate change scenario; under thinning, the climate change condition increased the growth of Scots pine up to $28 \%$ in the south and up to $54 \%$ in the north.

The predicted response to temperature, on the contrary, contradicts the suggestion by Cannell et al. (1989) that a $3{ }^{\circ} \mathrm{C}$ warming could result in a growth increase as high as 54\% under British conditions. This prediction, however, was derived from an analysis of growth sensitivity to temperature under boreal conditions and the authors warned that the response to temperature could flatten off at a July temperature of $15{ }^{\circ} \mathrm{C}$. Our results suggest that the relationship could be even reversed considering an increase in warming conditions.

A key role of low temperatures at the boreal limit (as well as at the altitudinal Grace 1988) and of water availability in the southern part of the range (Oberhuber et al. 1998) is confirmed by our regional analysis. The sites considered encompass much of the natural range of the species in western Europe (Boratynski 1991), covering a wide interval of latitude, temperature and water availability (Tab. 1). Simulation results are 
in good agreement with the conclusions of Ineson et al. (1984), who studied the productivity of Scots pine across Europe. From a re-analysis of a data-set of 18 P. sylvestris stands throughout Europe (Cannell 1982) by principal component analysis (PCA), they found that almost $50 \%$ of the variability in productivity was explained by the first eigenvalue, related to temperature, whilst an additional $26 \%$ was associated to the second PCA axis, related to precipitation. Once referenced to the climate of Europe, their results show a good agreement with the pattern resulting from the present paper.

The results are only partly confirmed, on the contrary, by the review of $P$. sylvestris growth and yield tables across Europe presented by Christie \& Lines (1979): height increments are quite similar across most of the temperate zone, but markedly lower in the boreal zone. Even greater differences are observed when volume increments are considered. On the other hand, the growth decline at southern and eastern locations predicted by the model is not apparent in growth and yield tables. This probably stems from the fact that simulations always refer to lowland sites, whilst $P$. sylvestris in these regions is more commonly found (and generally planted) at higher elevations and under moister conditions.

The use of a functional model makes it possible not only to predict, but also to understand the mechanisms behind such changes in forest productivity. Contrasting processes seem to be involved in the response of forest growth to limiting conditions under different climates (Fig. 8). Gross

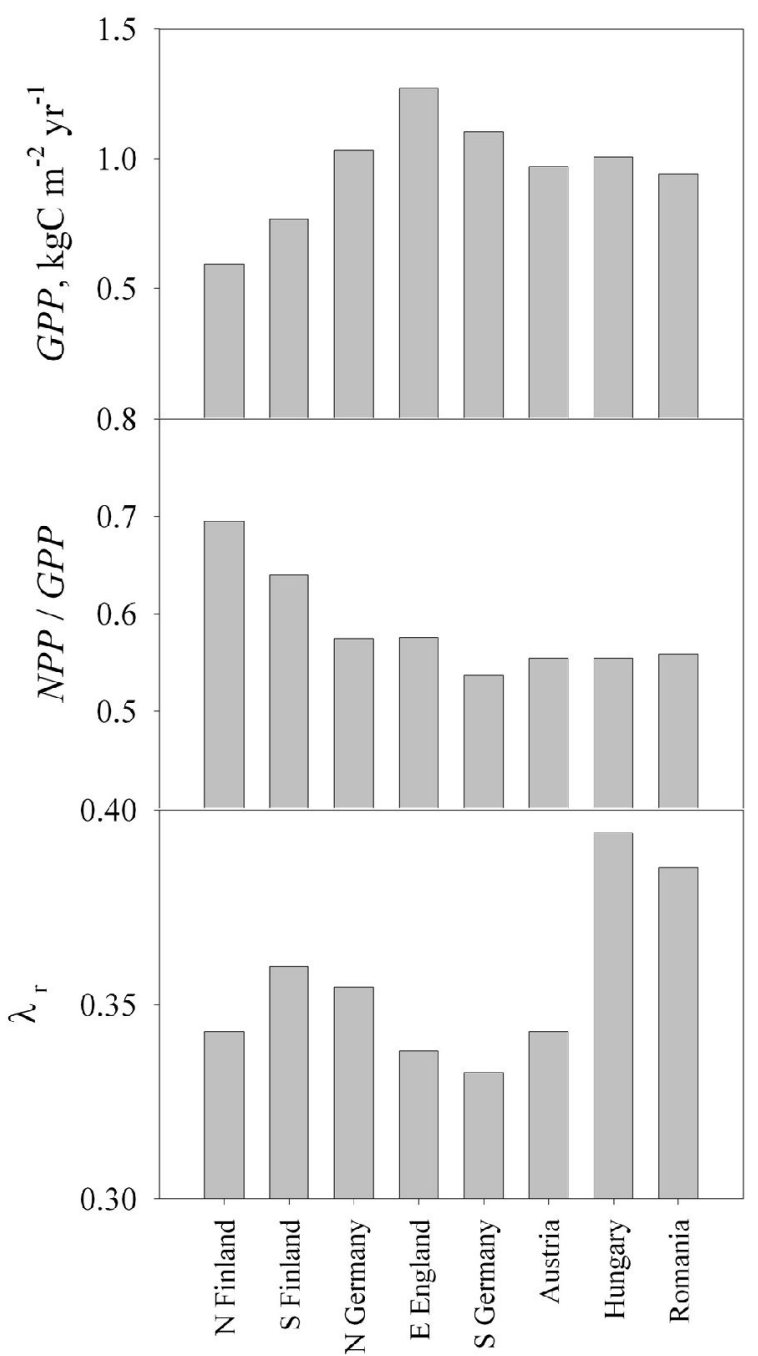

Fig. 8 - Simulated determinants of stand growth for a range of sites along two latitudinal and longitudinal transects across Europe. Mean values over 100 years of stand gross primary production (GPP), the ratio between net- and gross primary production (NPP / GPP) and the fraction of growth allocated to fine root production $\left(\lambda_{\mathrm{r}}\right)$ are reported.

Box 1 - Summary of parameter values used in computations. Several photosynthetic parameters related to the properties of Rubisco are as sumed to be invariant among $\mathrm{C}_{3}$ species and a value has been therefore derived from detailed analyses published in the literature (see De Pury \& Farquhar 1997). Maximum electron transport rate has been assumed to be linearly related to $\mathrm{V}_{\mathrm{c}}{ }^{\max }$ (Leuning 1997).

\begin{tabular}{|c|c|c|c|c|}
\hline Paramater & Definition & Units & Value & Source \\
\hline$a_{1}$ & coeff. in $g_{\mathrm{s}}$ vs $A$ equation & $\mathrm{Pa}^{-1}$ & $5.2 \times 10^{5}$ & Kellomäki \& Wang 1998 \\
\hline$D_{0}$ & coeff. in $g_{\mathrm{s}}$ response to vapour pressure deficit & $\mathrm{Pa}$ & 1200 & Wang 1996 \\
\hline$g_{0}$ & stomatal conductance to $\mathrm{CO} 2$ in darkness & $\mathrm{mol} \mathrm{m} \mathrm{m}^{-2} \mathrm{~s}^{-1}$ & $2.3 \times 10^{-3}$ & Kellomäki \& Wang 1998 \\
\hline$k_{\mathrm{fr}}$ & specific hydraulic conductance of fine roots & $\mathrm{m}^{3} \mathrm{~s}^{-1} \mathrm{MPa}^{-1} \mathrm{~kg}^{-1}$ & $2.3 \times 10^{-7}$ & $\begin{array}{l}\text { Roberts 1976, Roberts 1977, Magnani et al. } \\
2000\end{array}$ \\
\hline$k_{\mathrm{s}}$ & specific hydraulic conductivity of sapwood & $\mathrm{m}^{2} \mathrm{MPa}^{-1} \mathrm{~s}^{-1}$ & $1.3 \times 10^{-3}$ & Mencuccini \& Grace 1995 \\
\hline$l_{\mathrm{r}}$ & fine root longevity & Yr & 0.65 & Persson 1980 \\
\hline$l_{\mathrm{s}}$ & sapwood longevity & Yr & 39 & Helmisaari \& Siltala 1989 \\
\hline$N_{\mathrm{f}}$ & nitrogen concentration in foliage & $\mathrm{kg} \mathrm{N} \mathrm{kg}^{-1}$ & 0.015 & Mencuccini \& Grace 1996a \\
\hline$N_{\mathrm{r}}$ & nitrogen concentration in fine roots & $\mathrm{kg} \mathrm{N} \mathrm{kg}^{-1}$ & 0.0075 & Helmisaari \& Siltala 1989 \\
\hline$N_{\mathrm{s}}$ & nitrogen concentration in sapwood & $\mathrm{kg} \mathrm{N} \mathrm{kg}^{-1}$ & 0.0005 & Finn \& Braekke 1995 \\
\hline$r_{\mathrm{g}}$ & growth respiration coefficient & - & 0.28 & Chung \& Barnes 1977 \\
\hline$V_{\mathrm{c}}^{\max }$ & maximum carboxylation rate & $\mathrm{mol} \mathrm{m} \mathrm{s}^{-2}$ & $50 \times 10^{-6}$ & Kellomäki \& Wang 1998 \\
\hline$\alpha$ & photosynthetic quantum efficiency & mol e $^{-}$quantum ${ }^{-1}$ & 0.28 & Wang et al. 1996 \\
\hline$\rho_{\mathrm{f}}$ & $\begin{array}{l}\text { foliage density in the canopy (height } v s \text {. foliage } \\
\text { growth relationship) }\end{array}$ & $\mathrm{kg} \mathrm{m}^{-3}$ & 0.73 & Ovington 1957 \\
\hline$\Psi$ & critical leaf water potential & $\mathrm{MPa}$ & -1.4 & Magnani et al. 2000 \\
\hline$\Psi_{0}$ & soil $\Psi$ for maximum stomatal closure & $\mathrm{MPa}$ & -1.0 & Irvine et al. 1998 \\
\hline
\end{tabular}


primary production is reduced below its maximum value, corresponding to the British site, because of low temperatures and a short vegetative period, on the one hand, and of low air and soil humidity (as captured by the increasing PET / $P$ values in Tab. 1) on the other. The ratio between net and gross net primary production, in turn, is quite constant across all of the temperate region and only increases in the boreal zone, reflecting the pattern of annual mean temperature. Under dry conditions, on the contrary, aboveground productivity is most seriously hampered by the need to allocate increasing amounts of resources to fine root production and maintenance.

The potential relevance of tree structural acclimation for forest growth under dry conditions has already been stressed by Berninger \& Nikinmaa 1997, who considered in their simulations only potential changes in foliage-to-sapwood area ratio. In analogy with HYDRALl predictions, they suggested that a strong reduction in volume increments at the southern limit can only be explained by climate-induced changes in tree functional structure. An additional increase in carbon allocation below-ground, as predicted by the Hydrall model, could have even more important effects, because of the fast turnover rate of fine roots (Schoettle \& Fahey 1994, Konopka et al. 2005).

Such changes in allocation, however, although of utmost importance under dry conditions, have only a minor and not so clear effect when other climates are considered. This explains why they have been generally neglected in forest growth models, traditionally applied to boreal or temperate moist conditions (Ågren et al. 1991, Ågren et al. 1996). Explicit consideration of structural acclimation, on the other hand, appears to extend the generality of the HydraLl model to a wider range of environments.

These general considerations can be probably extended to other forest tree species. The pattern of forest productivity predicted by the Hydrall model is consistent with the results for Europe of the empirical model of Paterson (1956), who correlated maximum forest productivity for a large number of species with summary climatic statistics. This seems to suggest that, irrespective of the species considered, the same basic processes are at work in determining the response to climate of forest ecosystems.

\section{Acknowledgements}

The work was supported by the EU LTEEF-2 Project (Long-Term Regional Effects of Climate Change on European Forests: Impact Assessment and Consequences for Carbon Budgets) and by the Italian COFIN Projects: Impact of Climate Change on Forests and Wood Production (1998-2000) and Carbon balance and car- bon stocks in forest ecosystems: physiological determinants, age-related effects and environmental constraints (2000-2002). We gratefully thank the Climate Impacts LINK Project, UK Department of the Environment, Transport and the Regions (Contract Reference EPG 1/1/68) for producing the gridded climatology for Europe and Dr. R. Sievanen, Finnish Forest Research Institute, for providing the permanent plot data from the Vilppula site.

\section{References}

Ågren GI, McMurtrie RE, Parton WJ, Pastor J, Shugart HH (1991). State-of-the-art of models of production-decomposition linkages in conifer and grassland ecosystems. Ecological Applications 1: 118-138. - doi: 10.2307/1941806

Ågren GI, Johnson DW, Kirschbaum MUF, Bosatta E (1996). Ecosystem physiology-soil organic matter. In: "Global change: effects on forests and grasslands" (Breymeyer A, Hall DO, Melillo JM, Ågren GI eds). John Wiley \& Sons, Chichester, pp. 207-228.

Albrektson A, Valinger E (1985). Relations between tree height and diameter, productivity and allocation of growth in a Scots pine (Pinus sylvestris L.) sample tree material.In: "Crop physiology of forest trees" (Tigerstedt PMA, Puttonen P, Koski V eds). University of Helsinki, Helsinki, Finland, pp. 95-105.

Andrén O, Kätterer T (1997). ICBM: the introductory carbon balance model for exploration of soil carbon balances. Ecological Applications 7: 1226-1236. - doi: 10.1890/1051-0761(1997)007 [1226:ITICBM]2.0.CO;2

Andrén O, Paustian K (1987). Barley straw decomposition in the field: a comparison of models. Ecology 68: 1190-1200. - doi: 10.2307/ 1939203

Axelsson E, Axelsson B (1986). Changes in carbon allocation patterns in spruce and pine trees following irrigation and fertilization. Tree Physiology 2: 189-204. [online] URL: http://treephys.oxfordjournals.org/cgi/reprint/2/12-3/189.pdf

Bazire P, Gadant J (1991). La forêt en France. La Documentation Française, Paris, pp. 142.

Berninger F, Nikinmaa E (1997). Implications of varying pipe model relationships on Scots pine growth in different climates. Functional Ecology 11: 146-156. - doi: 10.1046/j.1365-2435.1997. 00067.x

Bird JA, Torn MS (2006). Fine roots vs. needles: a comparison of ${ }^{13} \mathrm{C}$ and ${ }^{15} \mathrm{~N}$ dynamics in a ponderosa pine forest soil. Biogeochemistry 79: 361382. - doi: 10.1007/s10533-005-5632-y

Boratynski A (1991). Range of natural distribution. In: "Genetics of Scots pine" (Giertych M, Matyas $\mathrm{C}$ eds). Elsevier, Amsterdam, The Netherlands, pp. 19-30.

Breymeyer AI, Hall DO, Melillo JM, Ågren GI (Eds.) (1996). Global change: effects on coniferous forests and grasslands. John Wiley, Chichester, USA, pp. 459

Briceno-Elizondo E, Garcia-Gonzalo J, Peltola H,
Matala J, Kelloma"ki S (2006). Sensitivity of growth of Scots pine, Norway spruce and silver birch to climate change and forest management in boreal conditions. Forest Ecology Management 232: 152167. - doi: 10.1016/j.foreco.2006. 05.062

Campbell GS (1985). Soil physics with BASIC. Transport models for soil-plant systems. Elsevier, Amsterdam, The Neteherlands, pp. 150.

Cannell MGR (1982). World forest biomass and primary production Data. Academic Press, New York, USA.

Cannell MGR, Dewar RC (1994). Carbon allocation in trees: a review of concepts for modelling. Advances in Ecololgical Research 25: 50-104.

Cannell MGR, Grace J, Booth A (1989). Possible impacts of climate warming on trees and forests in the United Kingdom: a review. Forestry 62: 337-364. - doi: 10.1093/forestry/62.4.337

Choudhury BJ, Monteith JL (1988). A four-layer model for the heat budget of homogeneous land surfaces. Quarterly Journal of the Royal Meteorological Society 114: 373-398. - doi: 10.1002/ qj.49711448006

Christie JM, Lines R (1979). A comparison of forest productivity in Britain and Europe in relation to climatic factors. Forest Ecology Management 2: 75-102. - doi: 10.1016/0378-1127(79) 90039-2

Chung HH, Barnes RL (1977). Photosynthate allocation in Pinus taeda. I. Substrate requirements for synthesis of shoot biomass. Canadian Journal of Forest Research 7: 106-111. - doi: 10.1139/ $\mathrm{x} 77-015$

Ciais P, Reichstein M, Viovy N, Granier A, Ogée J, Allard V, Aubinet M, Buchmann N, Bernhofer CHR, Carrara A, Chevallier F, De Noblet N, Friend AD, Friedlingstein $\mathrm{P}$, Grünwald T, Heinesch B, Keronen P, Knohl A, Krinner G, Loustau D, Manca G, Matteucci G, Miglietta F, Ourcival JM, Papale D, Pilegaard K, Rambal S, Seufert G, Soussana JF, Sanz MJ, Schulze ED, Vesala T, Valentini R (2005). Europe-wide reduction in primary productivity caused by the heat and drought in 2003. Nature 437: 529-534. - doi 10.1038/nature03972

De Pury DGG, Farquhar GD (1997). Simple scaling of photosynthesis from leaves to canopies without the errors of big-leaf models. Plant, Cell and Environment 20: 537-557. - doi: 10.1111/ j.1365-3040.1997.00094.x

Dewar RC (1997). A simple model of light and water use evaluated for Pinus radiata. Tree Physiology 17: 259-265. [online] URL: http://treephys.oxfordjournals.org/cgi/content/abstract/17/4/259

Edwards PN, Christie JM (1981). Yield models for forest management. Rep. 48, Forestry Commission Booklets, Forestry Commission, UK.

Eichorn F (1904). Beziehungen zwischen Bestandeshöhe und Bestandesmasse. Allgemeine Forst und Jagdzeitung 80: 45-49.

Farquhar GD, von Caemmerer S (1982). Modelling of photosynthetic response to environmental conditions. In: "Encyclopedia of Plant Physiology" (Lange OL, Nobel PS, Osmond CB, Zie- 
gler $\mathrm{H}$ eds). New Series. Vol. 12B. Physiological Plant Ecology II. Springer Verlag, Berlin, Germany, pp. 549-587.

Farquhar GD, Wong SC (1984). An empirical model of stomatal conductance. Australian Journal of Plant Physiolgy 11: 191-210. - doi: 10.1071/PP9840191

Finn H, Braekke F (1995). Response of understorey vegetation and Scots pine root systems to fertilization at multiple deficiency stress. Plant Soil 168-169: 179-185. - doi: 10.1007/ BF00029327

Friedlingstein P, Joel G, Field CB, Fungs IY (1999). Toward an allocation scheme for global terrestrial carbon models. Global Change Biology 5: 755-770. - doi: 10.1046/j.1365-2486. 1999.00269.x

Garratt JR (1992). The atmospheric boundary layer. Cambridge Univ. Press, Cambridge, UK, pp. 316.

Gholz HL, Linder S, McMurtrie RE (1994). Environmental constraints on the structure and productivity of pine forest ecosystems: a comparative analysis. Ecological Bulletins 43.

Goudriaan J, van Laar HH (1994). Modelling potential crop growth processes. Kluwer Academic Press, Dordrecht, The Netherlands, pp. 238.

Grace J (1988). Temperature as a determinant of plant productivity. In: "Plants and Temperature" (Long SP, Woodward FI eds). Society for Experimental Biology, UK, pp. 91-107. [online] URL: http://www.ncbi.nlm.nih.gov/pubmed/3270210

Helmisaari HS, Siltala T (1989). Variation in nutrient concentrations of Pinus sylvestris stems. Scandinavian Journal of Forest Research 4: 443451. - doi: 10.1080/02827588909382580

Hulme M, Conway D, Jones PD, Jiang T, Barrow EM, Turney C (1995). Construction of a 19611990 European climatology for climate change modelling and impact applications. International Journal of Climatology 15: 1333-1363. - doi: 10.1002/joc.3370151204

Högberg P, Nordgren A, Ågren GI (2002). Carbon allocation between tree root growth and root respiration in boreal pine forest. Oecologia 132: 579581. - doi: 10.1007/s00442-002-0983-8

Ineson P, Jones HF, Heal OW (1984). Regional aspects of forests in Europe: a preliminary study of Pinus sylvestris. In: "State and Change of Forest Ecosystems. Indicators in Current Research" (Ågren GI ed). Swed. Univ. Agric. Sci., Dept. Ecology and Environmental Research, Report No. 13, pp. 315-332.

Irvine J, Perks MP, Magnani F, Grace J (1998) The response of Pinus sylvestris to drought: stomatal control of transpiration and hydraulic conductance. Tree Physiology 18: 393-402. [online] URL: http://treephys.oxfordjournals.org/cgi/content/abstract/18/6/393

Jones HG (1992). Plants and microclimate $\left(2^{\text {nd }}\right.$ edn). Cambridge Univ. Press, Cambridge, UK, pp. 428.

Kellomäki S, Wang KY (1998). Daily and seasonal $\mathrm{CO}_{2}$ exchange in Scots pine grown under elevated $\mathrm{O}_{3}$ and $\mathrm{CO}_{2}$ : experiment and simulation. Plant Ecology 136: 229-248. - doi: 10.1023/

\section{A:1009708516072}

Kimball JS, Running SW, Nemani R (1997). An improved method for estimating surface humidity from daily minimum temperature. Agricultural and Forest Meteorology 85: 87-98. - doi: 10.1016/S0168-1923(96)02366-0

Konopka B, Curiel Yuste J, Janssens IA, Ceulemans R (2005). Comparison of fine root dynamics in Scots pine and pedunculate oak in sandy soil. Plant Soil 276: 3345. - doi: 10.1007/s11104004-2976-3

Kramer K, Leinonen I, Bartelink HH, et al. (2002). Evaluation of 6 process-based forest growth models based on eddy-covariance measurements of $\mathrm{CO}_{2}$ and $\mathrm{H}_{2} \mathrm{O}$ fluxes at 6 forest sites in Europe. Global Change Biology 8: 213-230. - doi: 10.1046/j.1365-2486.2002.00471.x

Kustas WP, Jackson RD, Asrar G (1989). Estimating surface energy-balance components from remotely sensed data. In: "Theory and Applications of Optical Remote Sensing" (Asrar G ed). Wiley, New York, USA, pp. 604-627.

Landsberg JJ, Waring RH (1997). A generalized model of forest productivity using simplified concepts of radiation-use efficiency, carbon balance and partitioning. Forest Ecology Management 95: 209-228. - doi: 10.1016/S0378-1127 (97)00026-1

Lapenis A, Shvidenko A, Shepaschenko D, Nilsson S, Aiyyer A (2005). Acclimation of Russian forests to recent changes in climate. Global Change Biology 11: 20902102. - doi: 10.1111/ j.1365-2486.2005.001069.x

Leuning R (1995). A critical appraisal of a combined stomatal-photosynthesis model for $\mathrm{C}_{3}$ plants. Plant, Cell and Environment 18: 339-355. - doi: 10.1111/j.1365-3040.1995.tb00370.x

Leuning R (1997). Scaling to a common temperature improves the correlation between the photosynthesis parameters $\mathrm{J}_{\max }$ and $\mathrm{V}_{\text {cmax }}$. Journal of Experimental Botany 48: 345-347. - doi: 10.1093/jxb/48.2.345

Litton CM, Raich JW, Ryan MG (2007). Carbon allocation in forest ecosystems. Global Change Biology 13: 2089-2109. - doi: 10.1111/j.13652486.2007.01420.x

Lloyd J, Taylor JA (1994). On the temperature dependence of soil respiration. Functional Ecology 8: 315-323. - doi: 10.2307/2389824

Magnani F (2000). Carbon allocation and tree growth under hydraulic constraints in Scots pine (Pinus sylvestris L.). PhD Thesis, University of Edinburgh, UK.

Magnani F, Centritto M, Grace J (1996). Measurement of apoplasmic and cell-to-cell components of root hydraulic conductance by a pressure clamp technique. Planta 199: 296-306. - doi: 10.1007/BF00196572

Magnani F, Mencuccini M, Grace J (2000). Agerelated decline in stand productivity: the role of structural acclimation under hydraulic constraints. Plant, Cell and Environment 23: 251263. - doi: 10.1046/j.1365-3040.2000.00537.x

Magnani F, Grace J, Borghetti M (2002). Adjustment of tree structure in response to the environment under hydraulic constraints. Functional
Ecology 16: 385-393. - doi: 10.1046/j.13652435.2002.00630.x

Magnani F, Consiglio L, Erhard M, Nolè A, Ripullone F, Borghetti M (2004). Growth patterns and carbon balance of Pinus radiata and Pseudotsuga menziesii plantations under climate change scenarios in Italy. Forest Ecology and Management 202: 93-105. - doi: 10.1016/j. foreco.2004.07.030

Maracchi G, Benincasa F, Zipoli G (1983). Elementi di Agrometeorologia. CNR-IATA, Firenze, pp. 76.

Mellander PE, Bishop K, Lundmark T (2004). The influence of soil temperature on transpiration: a plot scale manipulation in a young Scots pine stand. Forest Ecology and Management 195 1528. - doi: 10.1016/j.foreco.2004.02.051

Mencuccini M, Bonosi L (2001). Leaf/sapwood area ratios in Scots pine show acclimation across Europe. Canadian Journal of Forest Research 31: 442456 - doi: 10.1139/cjfr-31-3-442

Mencuccini M, Grace J (1995). Climate influences the leaf area-sapwood area ratio in Scots pine. Tree Physiology 15: 1-10. - doi: 10.1093/treephys/15.1.1

Mencuccini M, Grace J (1996a). Developmental patterns of above-ground xylem conductance in a Scots pine (Pinus sylvestris L.) age sequence. Plant, Cell and Environment 19: 939-948. - doi: 10.1111/j.1365-3040.1996.tb00458.x

Mencuccini M, Grace J (1996b). Hydraulic conductance, light interception and needle nutrient concentration in Scots pine stands and their relations with net primary productivity. Tree Physiology 16: 459-468. [online] URL: http://treephys.oxfordjournals.org/cgi/content/abstract/16/5/459

Monteith JL (1986). How do crops manipulate water supply and demand? Philos Trans R Soc Lond A Math Phys Sci 316:245-259. - doi: 10.1098/rsta.1986.0007

Monteith JL, Huda AKS, Midya D (1989). RESCAP: a resource capture model for sorghum and pearl millet. In: "Modelling the growth and development of sorghum and pearl millet" (Virmani SM, Tandon HLS, Alagarswamy G eds). ICRISAT Research Bulletin, Patancheru, India, pp. 30-34.

Monteith JL, Unsworth NH (1990). Principles of environmental physics ( ${ }^{\text {nd }}$ edn.). Edward Arnold, New York, USA, pp. 53-54.

Oberhuber W, Stumböck M, Kofler W (1998). Climate-tree-growth relationships of Scots pine stands (Pinus sylvestris L.) exposed to soil dryness. Trees 13: 19-27. - doi: 10.1007। PL00009734

Oleksyn J, Reich PB, Zytkowiak R, Karolewski P, Tjoelker MG (2003). Nutrient conservation increases with latitude of origin in European Pinus sylvestris populations. Oecologia 136 220-235. doi: 10.1007/s00442-003-1265-9

Ovington JD (1957). Dry-matter production by Pinus sylvestris L. Annals of Botany 21: 287314. [online] URL: http://aob.oxfordjournals.org/ cgi/content/abstract/21/2/287

Paterson SS (1956). The forest area of the world 
and its potential productivity. Dept. of Geography, Royal Univ. of Gothenburgh, Sweden.

Persson H (1980). Fine root dynamics in a Scots pine stand with and without near optimum nutrient and water regimes. Acta Phytogeographica Suecica 68: 101-110.

Poyatos R, Martínez-Vilalta J, Äermák J, Ceulemans R, Granier A, Irvine J, Köstner B, Lagergren F, Meiresonne L (2007). Plasticity in hydraulic architecture of Scots pine across Eurasia. Oecologia 153: 245-259. - doi: 10.1007/s00442 007-0740-0

Priestley CHB, Taylor RJ (1972). On the assessment of surface heat flux and evaporation using large scale parameters. Monthly Weather Review 100: 81-92. - doi: 10.1175/1520-0493(1972)100 $<0081$ :OTAOSH $>2.3 . \mathrm{CO} ; 2$

Roberts J (1976). A study of root distribution and growth in a Pinus sylvestris L. (Scots pine) plantation in East Anglia. Plant Soil 44X: 607-621. doi: 10.1007/BF00011380

Roberts J (1977). The use of tree-cutting techniques in the study of the water relations of mature Pinus sylvestris L. Journal of Experimental Botany 28: 751-767. - doi: 10.1093/jxb/28.3.751

Ross J (1981). The radiation regime and architecture of plant stands. Dr. W. Junk Publishers, The Hague, The Netherlands, pp. 391.

Ryan MG (1991). A simple method for estimating gross carbon budgets for vegetation in forest ecosystems. Tree Physiology 9: 255-266. [online] URL: http://treephys.oxfordjournals.org/cgi/reprint/9/1-2/255.pdf

Ryan MG (1995). Foliar maintenance respiration of sub-alpine and boreal trees and shrubs in relation to nitrogen content. Plant, Cell and Environment 18: 765-772. - doi: 10.1111/j.13653040.1995.tb00579.x

Santantonio D (1989). Dry-matter partitioning and fine root production in forests. New approaches to a difficult problem. In: "Biomass production by fast-growing trees" (Pereira JS, Landsberg JJ eds). Kluwer Academic Publisher, Dordrecht, The Netherlands, pp. 57-72. [online] URL: http:// cat.inist.fr/?aModele $=$ afficheN\&cpsidt $=7273833$ Schar C, Vidale PL, Luthi D, Frei C, Haberli C, Liniger MA, Appenzeller C (2004). The role of increasing temperature variability in European summer heatwaves. Nature 427: 332-335. - doi: 10.1038/nature 02300

Schoettle AW, Fahey TJ (1994). Foliage and fine root longevity of pines. Ecological Bulletins 32: 136-153. [online] URL: http://www.jstor.org/ stable/20113137

Sevola Y (1998). Statistical yearbook of forestry. Finnish Forest Research Institute, Helsinki, Finland.

Shaw RH, Pereira AR (1982). Aerodynamic roughness of a plant canopy: a numerical experiment. Agricultural Meteorology 26: 51-65. - doi: 10.1016/0002-1571(82)90057-7

Thornley JHM, Johnson IR (1990). Plant and crop modelling. Clarendon Press, Oxford, UK.

Tjoelker MG, Oleksyn J, Reich PB (2001). Modelling respiration of vegetation: evidence for a general temperature-dependent $\mathrm{Q}_{10}$. Global Change Biology 7: 223-230. - doi: 10.1046/j.13652486.2001.00397.x
Tyree MT, Sperry JS (1989). Vulnerability of xylem to cavitation and embolism. Annual Review of Plant Physiolgy 40: 19-38. - doi: 10.1146/annurev.pp.40.060189.000315

Wang K-Y (1996). Canopy $\mathrm{CO}_{2}$ exchange of Scots pine and its seasonal variation after four-year exposure to elevated $\mathrm{CO}_{2}$ and temperature. Agricultural and Forest Meteorolgy 82: 1-27. - doi: 10.1016/0168-1923(96)02342-8

Wang KY, Kellomäki S, Laitinen K (1996). Acclimation of photosynthetic parameters in Scots pine after three years exposure to elevated temperature and $\mathrm{CO}_{2}$. Agricultural and Forest Meteorolgy 82: 195-217. - doi: 10.1016/01681923(96)02329-5

Waring RH, Landsberg JJ, Williams M (1998). Net primary production of forests: a constant fraction of gross primary production? Tree Physiology 18: 129-134. [online] URL: http://treephys.oxfordjournals.org/cgi/content/abstract/18/2/129

Westoby M (1984). The self-thinning rule. Advances in Ecololgical Research 14: 167-225. doi: 10.1016/S0065-2504(08)60171-3

White EJ (1982). Relationship between height growth of Scots pine and site factors in Great Britain. Forest Ecology Management 4: 225-245. - doi: 10.1016/0378-1127(82)90002-0

Whitehead D, Edwards WRN, Jarvis PG (1984). Conducting sapwood area, foliage area, and permeability in mature trees of Picea sitchensis and Pinus contorta. Canadian Journal of Forest Research 14: 940-947. - doi: 10.1139/x84-166 